\title{
Perancangan dan I mplementasi Sistem Remote Tilting Antenna untuk Aplikasi Base Station
}

\author{
ARSYAD RAMADHAN DARLIS
}

\author{
Teknik Elektro Institut Teknologi Nasional \\ Email : arsyad@itenas.ac.id
}

\begin{abstract}
ABSTRAK
Pada kondisi pembangunan suatu jaringan seluler baru, permasalahan coverage area terkadang perlu penanganan khusus. Jika coverage area dari suatu base station terlalu besar maka dapat mengakibatkan saling tumpang tindih (overlap) dengan sel yang berdekatan. $\mathrm{Hal}$ ini akan meningkatkan interferensi daya antar sel, yang kemudian berakibat pada penurunan kualitas layanan. Salah satu bentuk solusi untuk dapat memenuhi persyaratan coverage area, kinerja jaringan seluler, dan juga memenuhi tingkat keselamatan engineer adalah dengan menggunakan metoda down tilting antenna melalui wireless. Penetapan metoda down tilting antenna dilakukan dengan membuat suatu peralatan yang dapat menggerakkan posisi antenna pada base station. Perangkat yang diimplementasikan terdiri atas Transmitter, Receiver, Motor DC, Driver Motor, Logam Pengait, dan Antena. Sinyal yang berfungsi sebagai pengendali masuk ke Transmitter dan selanjutnya diolah oleh Receiver. Sinyal keluaran dari Receiver digunakan untuk mengendalikan motor DC melalui driver motor yang mengendalikan pergerakan dari Antenna Base Station. Pada penelitian ini, sistem telah dapat diuji memalui pergerakan antenna sampai dengan jarak $10 \mathrm{~m}$. Tingkat kemiringan antena dibandingkan dengan pergeseran logam berkait menunjukan hasil yang linear. Setiap pergeseran 0,5 cm akan menyebabkan perubahan kemiringan antenna sebesar 1 derajat.
\end{abstract}

Kata kunci: Remote Tilting, Motor DC, Transmitter, Receiver, Base Station

\begin{abstract}
On the state of development of a new mobile network, problem coverage area sometimes need special handling. If the coverage area of a Base Station is too big then it may lead to overlap ( overlap ) with adjacent cells. This will improve inter-cell interference power, which then resulted in a decrease in the quality of service. One form of solutions to meet the requirements of the coverage area, the performance of cellular networks, and also meet the level of safety engineers is to use the method of tilting down through a wireless antenna. Determination method of antenna down tilting is done by creating a device that can move the position of the antenna on Base Station. The device is implemented consisting of Transmitter, Receiver, Motor DC Motor Driver, Metal Hook, and Base Station Antennas. Which serves as a signal controlling entry into Transmitter and subsequently processed by the Receiver. The output signal of the receiver is used to control a DC motor through a motor driver that controls the movement of Base Station Antenna. In this study, the system has to be tested memalui antenna movement up to a distance of $10 \mathrm{~m}$. Levels compared to the friction slope antenna hooked metal has showed linear results. Each shift will lead to a change of $0.5 \mathrm{~cm}$ by 1 degree slope antenna.
\end{abstract}

Key words : Remote Tilting, DC Motor, Transmitter, Receiver, Base Station

Jurnal Elkomika - 93 


\section{PENDAHULUAN}

Permasalahan untuk mendapatkan coverage area yang sesuai tidak hanya terbatas pada kondisi perubahan frekuensi pada jaringan yang telah terbentuk, seperti yang telah dilakukan pada saat ini dimana terjadi regulasi perubahan frekuensi kerja jaringan seluler dari $1900 \mathrm{MHz}$ ke $800 \mathrm{MHz}$. Pada kondisi pembangunan suatu jaringan seluler baru, permasalahan coverage area terkadang perlu penanganan khusus. Jika coverage area dari suatu base station terlalu besar maka dapat mengakibatkan saling tumpang tindih (overlap) dengan sel yang berdekatan. Hal ini akan meningkatkan interferensi daya antar sel, yang kemudian berakibat pada penurunan kualitas layanan.

Salah satu bentuk solusi untuk dapat memenuhi persyaratan coverage area, kinerja jaringan seluler, dan juga memenuhi tingkat keselamatan engineer adalah dengan menggunakan metoda down tilting antenna menggunakan wireless. Down tiliting antenna merupakan metoda pergeseran sudut kecuraman antena untuk mendapatkan coverage area yang diinginkan (Prasad, 2005; Folker,2006). Penetapan metoda down tilting antenna dilakukan dengan membuat suatu peralatan yang dapat menggerakkan posisi antenna pada BTS dengan akurasi pergeseran sudut pancar yang baik dan kemudahan dalam pengoperasiannya (Benner, 1996).

Secara utuh kegiatan penelitian ini bertujuan untuk dapat menghasilkan perangkat mechanical down-tilting antenna yang dapat dikendalikan dari jarak jauh. Untuk itu, akan dilakukan rancang bangun dua buah sistem pendukung utama, yaitu sistem penggerak antena sector pada Base Station dan sistem pengendali penggerak antena jarak jauh berbasis gelombang radio. Adapun manfaat dari penelitian ini adalah memberikan kemudahan dalam penerapan metoda down-tilting antenna karena dilakukan secara jarak jauh, mengurangi kebutuhan banyak kabel karena untuk keperluan transmisi sinyal pengendali sistem penggerak antena dan informasi kedudukan sudut terakhir, dilakukan dengan menggunakan gelombang radio, Lebih murah karena menggunakan komponen komponen pendukung yang terdapat di dalam negeri, dan tidak perlu mengkhawatirkan keselamatan engineer, karena sistem kendali dilakukan di bawah tower melalui wireless.

Adapun yang menjadi batasan masalah dari pokok bahasan penelitian ini adalah jenis motor yang digunakan pada penelitian ini adalah motor DC dengan tegangan input 32 volt, modulasi yang digunakan pada penelitian ini adalah modulasi digital, dan antena yang digunakan sebagai prototype adalah antena mikrostrip yang digunakan pada antena base station saat ini. 


\section{METODOLOGI PERANCANGAN}

Sistem Remote Tilting Antenna yang akan dirancang dan diimplementasikan terlihat pada Gambar 1 dibawah ini :

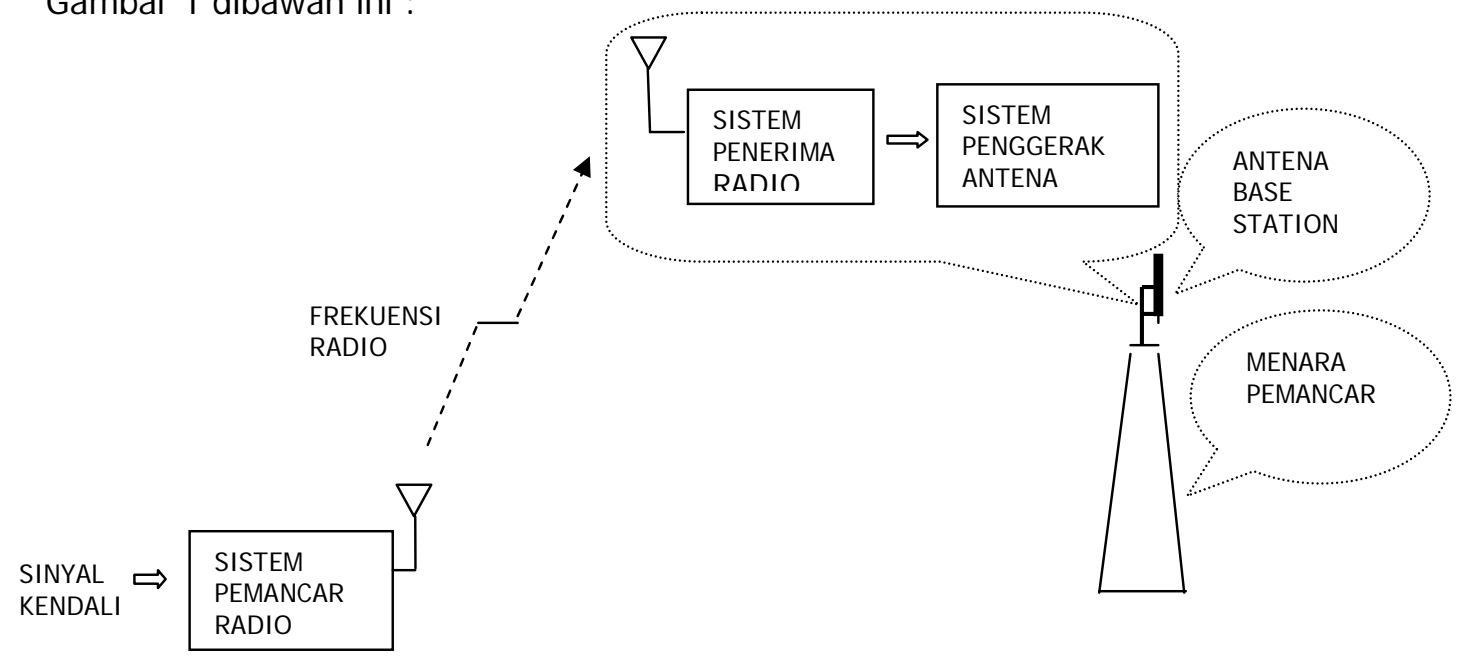

\section{Gambar 1. I lustrasi Sistem yang akan direalisasikan}

Pada Gambar 1 tersebut terlihat bahwa komponen - komponen yang membentuk sistem ini adalah sebagai berikut :
a. Sistem Pemancar Radio ( Transmitter)
b. Sistem Penerima Radio ( Receiver)
c. Sistem Penggerak Antena
d. Antenna Base Station

Pada bab ini akan dibahas mengenai perancangan dan implementasi masing - masing komponen sistem pembentuk Remote Tilting ini.

\subsection{Sistem Pemancar Radio ( Transmitter)}

Sistem pemancar radio berfungsi untuk mengirimkan sinyal yang akan mengendalikan pergerakan motor di atas menara pemancar ( tower) sehingga antenna akan dapat diatur dari jarak jauh. Sinyal kendali yang masuk ke dalam system pemancar akan dimodulasi oleh sinyal carrier yang memiliki frekuensi lebih besar dibandingkan dengan sinyal informasi atau sinyal kendalinya. Frekuensi sinyal modulasi yang digunakan pada penelitian ini adalah 27 $\mathrm{MHz}$. Sedangkan modulasi yang digunakan adalah modulasi digital dengan jenis Frekuensi Shift Keying ( FSK ) (Asep, 2008). Sinyal hasil modulasi kemudian akan dikuatkan dengan menggunakan rangkaian amplifier sehingga akan kuat untuk ditransmisikan. Setelah dikuatkan, sinyal hasil penguatan akan ditransmisikan dengan menggunakan sebuah antenna yang akan mengkonversi sinyal listrik menjadi induksi elektromagnetik. Jenis antena yang digunakan adalah antena vertikal yang hanya terdiri atas sebuah kawat panjang. Pada penelitian ini sistem pemancar radio telah terintegrasi dalam sebuah alat. Gambar 2 dibawah ini menunjukan sistem pemancar yang digunakan dalam penelitian ini. 

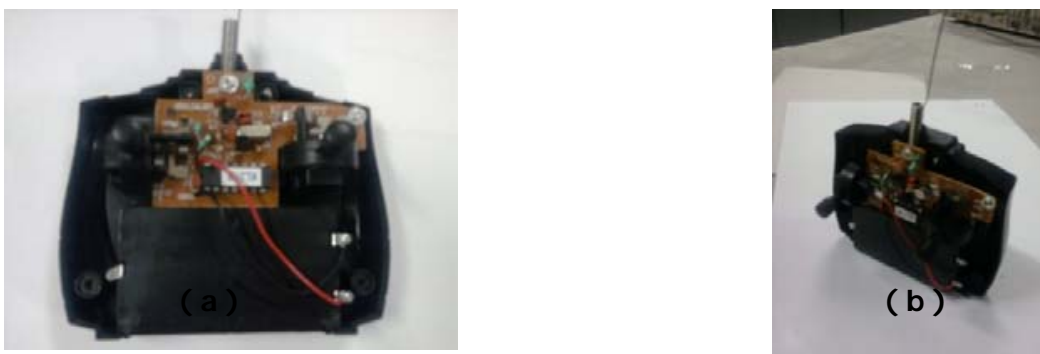

Gambar 2. Sistem Pemancar Radio ( a) Tampak Depan ( b ) Tampak Samping

\subsection{Sistem Penerima Radio ( Receiver)}

Sinyal yang dikirimkan oleh sistem pemancar akan diterima oleh sistem penerima radio yang akan mengembalikan sinyal tersebut menjadi sinyal informasi atau kendali seperti sebelum dikirimkan di transmitter. Sinyal yang telah diterima tersebut akan diproses lebih lanjut oleh driver dari sistem penggerak motor yang berbentuk dua buah rangkaian yang sama. Gambar 3 menunjukan sistem penerima yang telah direalisasikan.

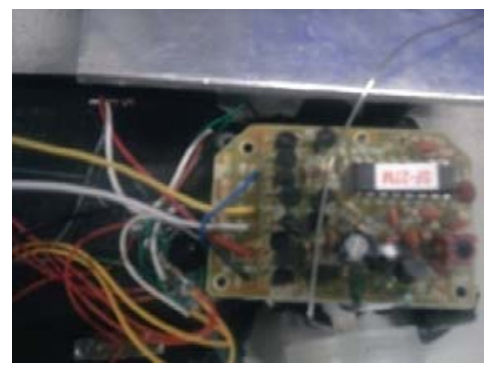

\section{Gambar 3. Sistem Penerima Radio}

\subsection{Sistem Penggerak Antena}

Berdasarkan blok diagram pada Gambar 4 sistem ini dibagi menjadi tiga bagian yaitu Motor, Interface Motor - Antena yang berupa logam berkait, dan Driver Motor.

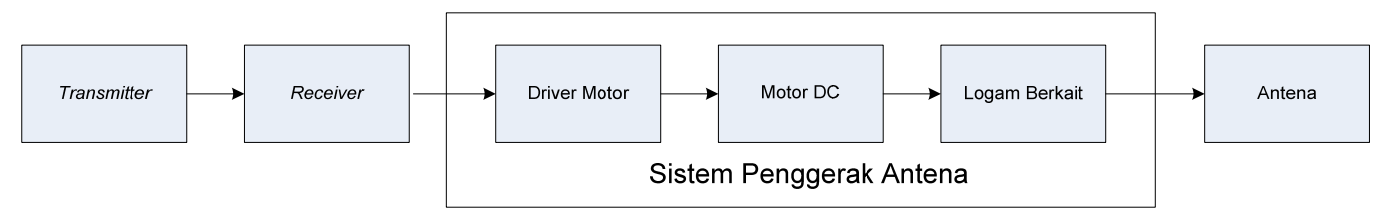

\section{Gambar 4. Blok Diagram Sistem Penggerak Antena}

Motor yang digunakan pada penelitian ini adalah motor DC yang akan berfungsi apabila dicatu dengan menggunakan tegangan DC. Motor ini berfungsi mengubah energi listrik menjadi energi mekanik (Paul, 2000). Tegangan yang dihasilkan berasal dari driver motor yang akan menggerakan motor sesuai dengan polaritasnya. Gambar 5 menunjukan motor DC yang digunakan pada penelitian ini. 


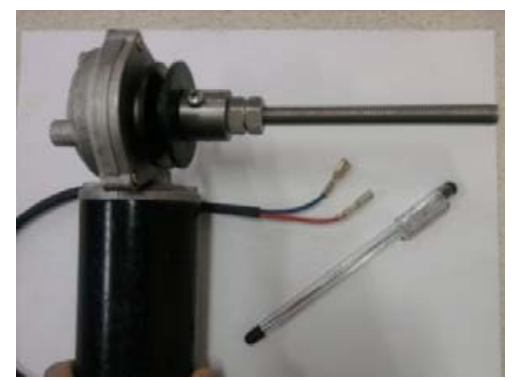

Gambar 5. Motor DC

Motor DC ini dapat bekerja dengan baik pada range catu daya dari 1 Volt sampai dengan 200 Volt. Semakin besar catu daya yang digunakan maka akan semakin cepat perputaran dari motor. Pada penelitian ini digunakan catu daya sebesar 32 Volt yang merupakan nilai maksimum dari instrumen Power Supply yang ada di Laboratorium.

Untuk menghubungkan motor DC dengan antena diperlukan sebuah bahan yang akan dipasangkan pada antena yang akan digunakan. Bahan ini terbuat dari logam dengan sebuah kaitan. Bahan ini pula akan dipasangkan pada ulir di motor DC. Dengan demikian, motor berputar maka pergerakan ulir akan mengarah ke depan ataupun ke belakang. Gambar 6. menunjukan bahan mekanik yang merupakan bagian dari sistem penggerak antena.

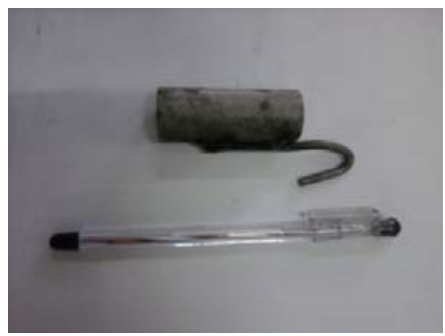

\section{Gambar 6. Logam berkait penghubung Motor DC dengan Antena}

Gambar 7 menunjukan motor DC dengan input tegangan 32 volt yang dihubungkan kepada pengait yang digunakan pada penelitian ini.

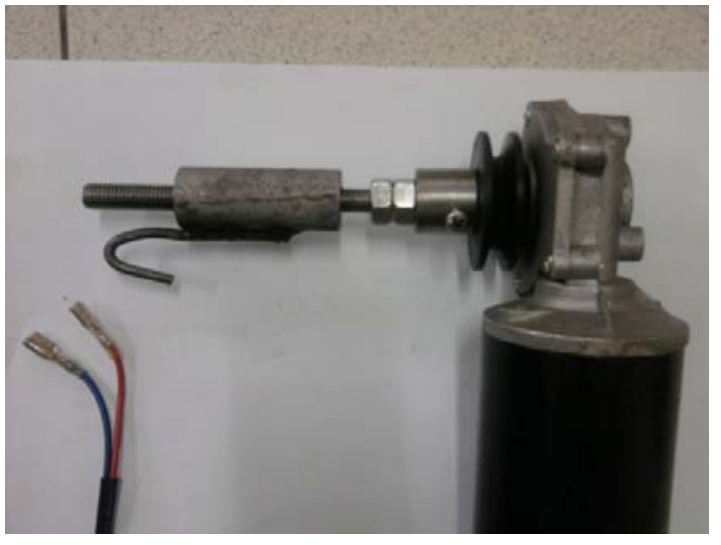

Gambar 7. Sistem Motor DC dengan logam berkait 
Driver motor berfungsi untuk mengkonversi tegangan keluaran dari system penerima menjadi tegangan yang diperlukan oleh motor. Rangkaian yang akan diimplementasikan ada dua buah yang merupakan rangkaian driver untuk supply positif dan supply negatif. Hal ini akan menentukan pergerakan dari antena melalui motor DC. Dengan supply negatif akan membuat motor DC berputar ke kanan yang dapat berarti antena akan maju ke depan dan sebaliknya supply positif akan membuat motor DC berputar ke kiri dan antena akan mundur ke belakang. Gambar 8 menunjukan rangkaian driver yang digunakan sebagai driver motor DC.

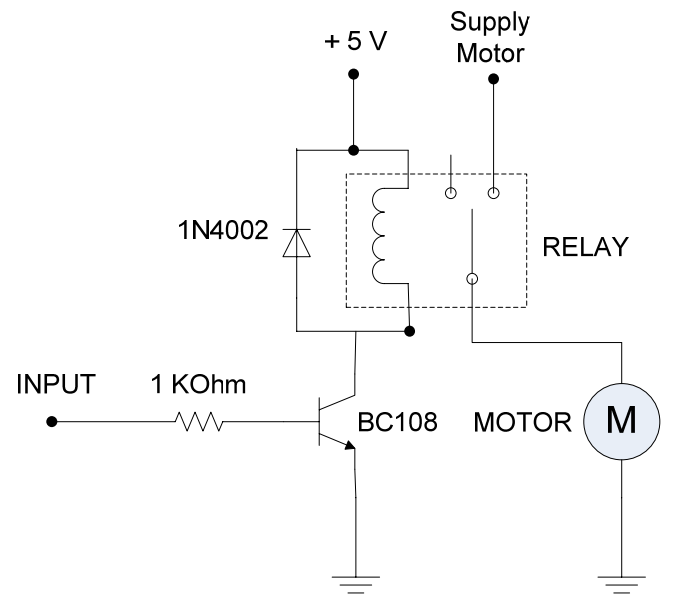

Gambar 8. Rangkaian Driver Motor

Tabel 1 menunjukan komponen - komponen yang digunakan dalam mengimplementasikan Driver Motor DC. Resistor $1 \mathrm{kOhm}$ digunakan untuk meredam arus yang berasal dari input agar tidak terlalu besar. Transistor disini berfungsi sebagai saklar yang akan menentukan tegangan 5 Volt mengalit atau tidak. Apabila tegangan input berpolaritas positif, maka akan menyebabkan transistor forward bias. Hal ini akan menyebabkan transistor mengalami short circuit sehingga tegangan 5 volt akan mengalir ke lilitan yang terdapat pada relay. Dioda berfungsi sebagai pengaman agar tidak ada arus yang mengalir ke sumber tegangan. Dengan dialirinya lilitan oleh arus listrik, maka switch akan terhubung ke supply motor 32 volt sehingga motor akan berputar.

Tabel 1. Komponen Driver Motor DC

\begin{tabular}{|c|c|c|}
\hline No. & Komponen & Jumlah \\
\hline 1 & Resistor 1 kOhm & 1 Buah \\
\hline 2 & Transistor BC108 & 1 Buah \\
\hline 3 & Dioda 1N4002 & 1 Buah \\
\hline 4 & Relay SPDT & 1 Buah \\
\hline
\end{tabular}

Gambar 9 menunjukan dua buah rangkaian driver motor DC yang telah diimplementasikan. Rangkaian tersebut digunakan untuk menggerakan motor dengan menggunakan tegangan input yang kecil. Tegangan -32 volt dan 32 volt digunakan agar motor dapat berputar searah dan berlawanan arah jarum jam. 


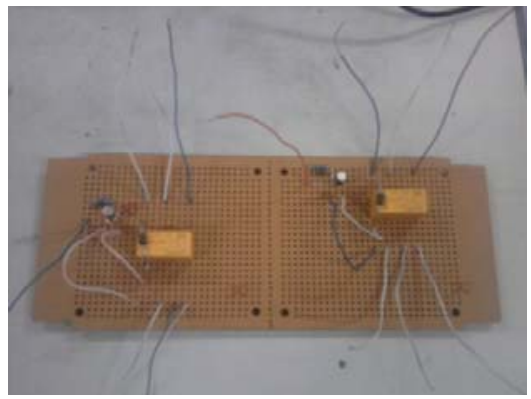

Gambar 9. Dua Buah DriverMotor DC dengan dua buah polaritas positif dan negatif

Dan Gambar 10 dibawah ini menunjukan gambar sistem yang digunakan untuk menggerakkan penggerak antenna secara utuh. Gambar tersebut menunjukan antena yang terpasang ke motor melalui logam berkait.

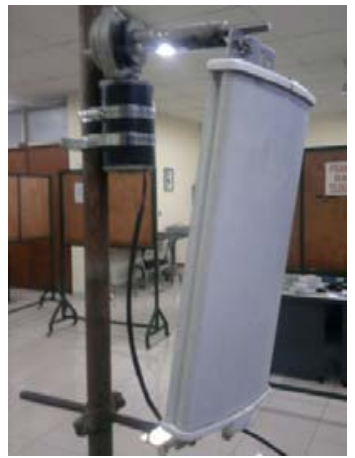

( a )

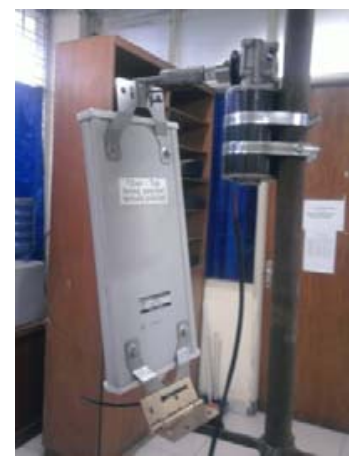

( b )

\section{Gambar 10. Sistem Penggerak Antena Base Station ( a ) Tampak Depan ( b ) Tampak Samping}

\subsection{Antena Base Station}

Pada penelitian ini, antena yang digunakan merupakan antenna base station yang sesungguhnya digunakan pada aplikasi secara real. Jenis antenna yang digunakan sebagai model disini adalah antenna sektoral yang hanya memiliki sebuah pola radiasi saja. Antena ini akan dihubungkan kepada motor DC melalui logam berkait. Gambar 11 menunjukan jenis antena yang digunakan.

Antena ini akan diatur tingkat kemiringannya oleh motor DC. Perubahan sudut kemiringan akan berpengaruh terhadap kapasitas pelayanan user. Tingkat kemiringan antena dilakukan perubahan sesuai dengan kebutuhan operator itu sendiri. 


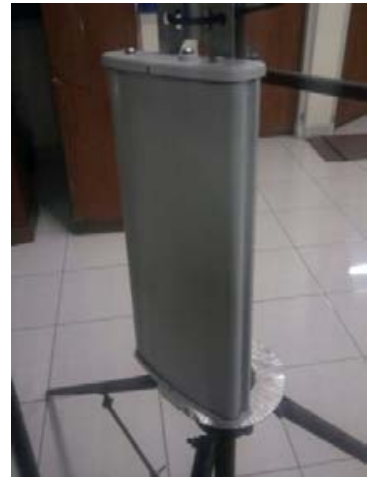

( a )

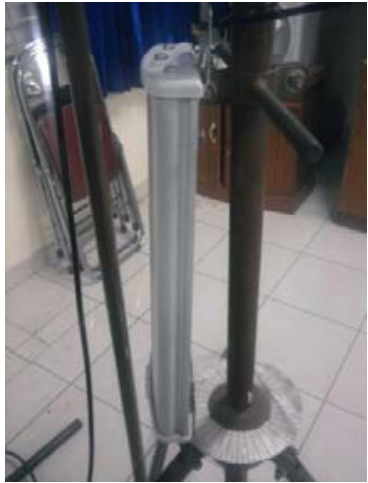

( b )

Gambar 11. Antena Base Station ( a ) Tampak Depan ( b ) Tampak Samping

\section{HASI L PERANCANGAN DAN PEMBAHASAN}

Setelah sistem berhasil diimplementasikan, maka diperlukan beberapa pengujian untuk mengukur kinerja dari sistem tersebut. Adapun blok diagram dari sistem yang telah diimplementasikan ditunjukan oleh Gambar 12.

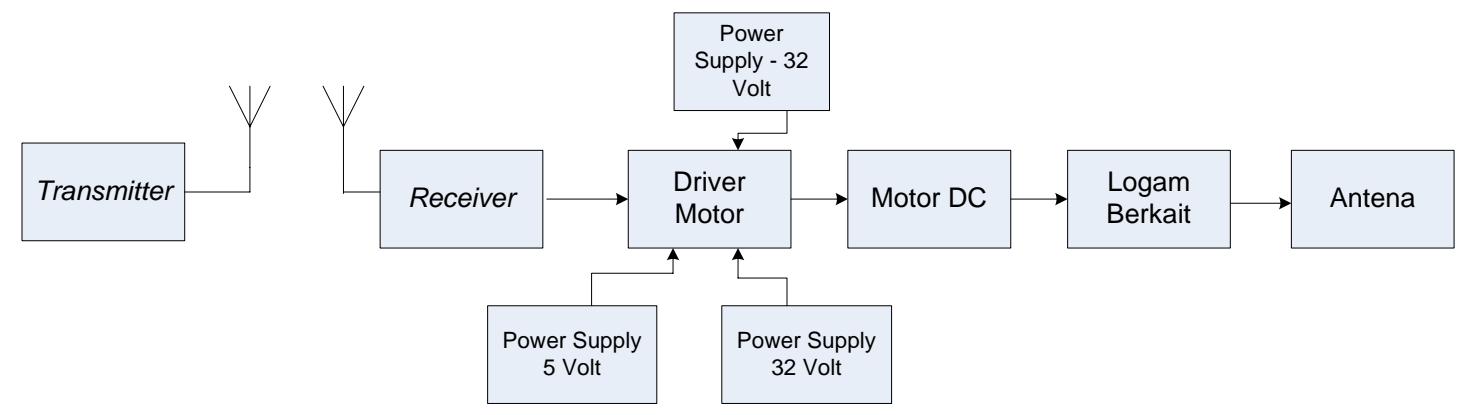

Gambar 12. Blok diagram sistem remote tilting yang telah direalisasikan

Sinyal kendali yang dibangkitkan akan dimodulasi oleh sinyal pembawa ( carrier) oleh transmitter dan kemudian dikuatkan oleh rangkaian amplifier. Sinyal tersebut kemudian ditransmisikan melalui media nirkabel ( wireless) sehingga sampai ke sistem penerima ( receiver ). Sinyal yang diterima oleh sistem penerima akan diubah kembali menjadi sinyal kendali yang sama seperti sebelum dikirimkan oleh transmitter. Akan tetapi pada proses pada transceiver ( transmitter - receiver ) terjadi pelemahan amplitude pada sinyal yang diterima. Pada awalnya sinyal kendali memiliki amplitude sebesar 5 Volt, sedangkan pada sinyal kendali yang diterima amplitude hanya sebesar 3,46 Volt. Hal ini disebabkan terjadi redaman yang disebabkan oleh noise baik eksternal maupun internal. Akan tetapi walaupun demikian, tegangan yang diterima sudah cukup untuk men-trigger driver motor.

Sinyal yang diterima akan masuk ke driver motor DC. Sebagaimana yang telah dijelaskan pada bab sebelumnya, driver ini berfungsi untuk mengkonversi tegangan dari tegangan input yang hanya 3,46 Volt ke tegangan yang dapat menggerakan motor DC yaitu pada penelitian ini digunakan tegangan supply sebesar 32 Volt. Tegangan 3,46 Volt tidak cukup besar untuk menggerakan putaran motor yang dibutuhkan. Rangkaian yang diimplementasikan terdiri atas dua buah rangkaian. Rangkaian pertama akan menghasilkan tegangan 32 Volt dan 
rangkaian kedua akan menghasilkan tegangan - 32 Volt. Hal ini diperlukan untuk memutarkan motor DC searah atau berlawanan jarum jam. Apabila diberikan tegangan 32 Volt maka motor akan berputar searah jarum jam dan apabila sebaliknya diberikan tegangan - 32 Volt, maka putaran motor akan berlawanan arah jarum jam.

Putaran motor yang searah jarum jam akan mengakibatkan ulir yang dirancang bergerak sesuai dengan putaran motor. Hal ini menyebabkan logam berkait akan bergerak maju karena logam ini dikaitkan ke antenna sehingga tidak akan mengalami perubahan posisi. Dengan adanya pergerakan maju dari logam berkait ini akan menyebabkan antena bergerak maju pula sehingga tingkat kemiringan akan berubah membesar terhadap sumbu tegak. Begitupula sebaliknya dengan perubahan tegangan dari 32 Volt ke - 32 Volt. Hal ini menyebabkan sudut kemiringan antena terhadap sumbu tegak akan mengecil. Hal ini ditunjukan pada Gambar 13. Perubahan tegangan ini ditentukan tergantung dari user dengan menggunakan remote control pada transmitter yang akan membangkitkan sinyal kendali.

Pada subbab ini akan dilakukan beberapa buah pengujian, yaitu sebagai berikut :

1. Pengujian sistem berdasarkan pergerakan antena.

2. Pengujian sistem berdasarkan jarak jangkauan

3. Pengujian sistem berdasarkan tingkat kemiringan antena

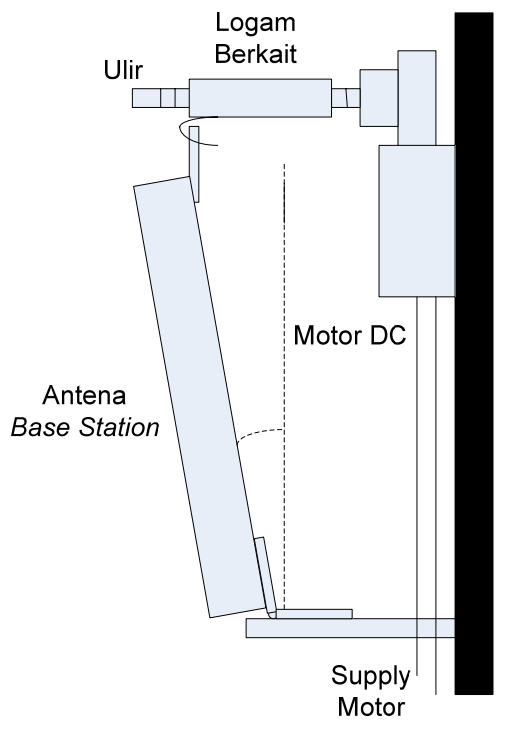

Gambar 13. I lustrasi Sistem Tilting Antena dengan kemiringan tertentu

\subsection{Pengujian sistem berdasarkan pergerakan antena.}

Pengujian ini dilakukan dengan mengubah posisi stick yang berada di sebelah kiri dari tengah ke atas, seperti yang ditunjukan pada Gambar 14, ataupun dengan mengubah posisi stick yang berada di sebelah kanan dari tengah ke kiri, seperti yang ditunjukan pada Gambar 15 . 


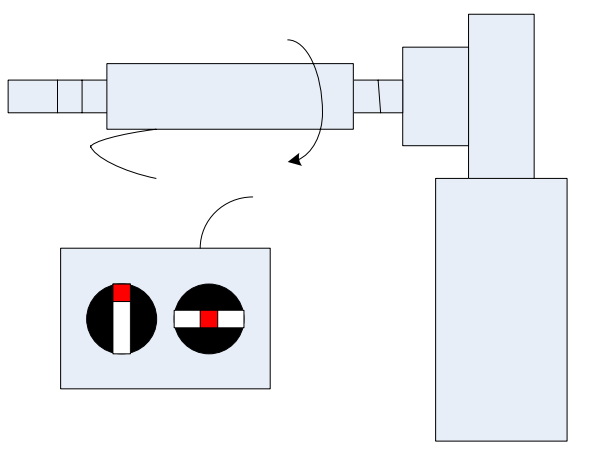

Gambar 14. Gerak motor DC searah dengan jarum jam sesuai dengan remote control

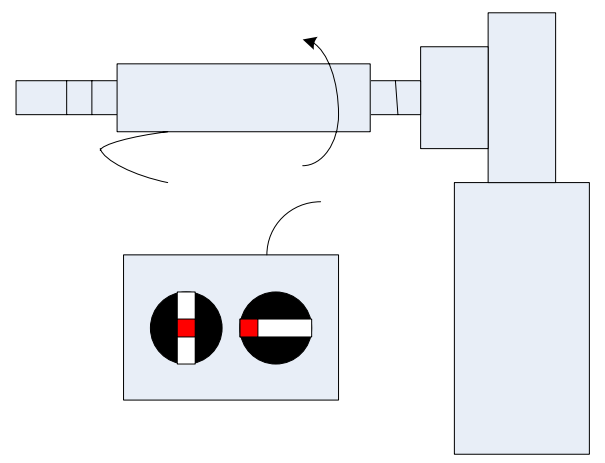

Gambar 15. Gerak motor DC berlawanan dengan jarum jam sesuai dengan remote control

Pada pengujian ini terbukti bahwa antena dapat bergerak maju ataupun mudursesuai dengan arah gerak stick dari remote control. Hal ini membuktikan bahwa pada dasarnya penelitian ini telah berhasil dengan baik.

\subsection{Pengujian sistem berdasarkan jarak jangkauan}

Pengujian ini dilakukan untuk menunjukan kinerja sistem terhadap jarak jangkau yang menunjukan jangkauan dari sistem remote tilting ini. Ilustrasi dari pengujian ini dapat terlihat pada Gambar 16 dibawah ini.

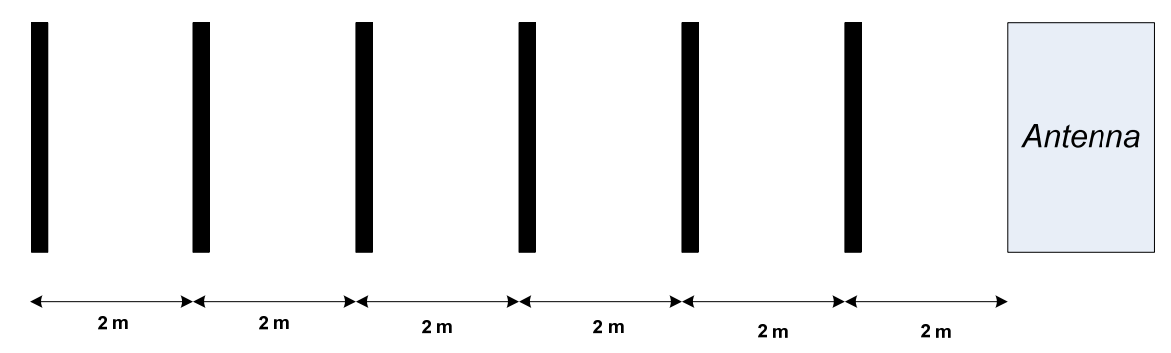

\section{Gambar 16. Pengujian remote tilting antenna berdasarkan jarak jangkauan}

Pada pengujian ini dilakukan reaksi dari antenna terhadap jarak yang telah diatur. Yang dimaksud dengan reaksi disini adalah bergerak atau tidaknya antena pada suatu jarak tertentu. Apabila pada jarak tertentu setelah dilakukan pengujian, antena bergerak maju ataupun mundur, maka akan menjadi tolak ukur bahwa sistem ini berhasil. Jarak yang digunakan pada setiap pengujian adalah setiap 2 meter dimulai dari posisi terdapatnya antena. Hasil pengujian ditunjukan pada Tabel 2 dibawah ini. 
Tabel 2. Hasil Pengujian sistem berdasarkan jarak jangkauan

\begin{tabular}{|c|c|c|}
\hline \multicolumn{2}{|c|}{$\begin{array}{c}\text { Jarak } \\
\text { ( meter) }\end{array}$} & \multirow{2}{*}{$\begin{array}{c}\text { Kondisi } \\
\text { Berputar lancar }\end{array}$} \\
\hline 0 & 2 & \\
\hline 2 & 4 & Berputar lancar \\
\hline 4 & 6 & Berputar lancar \\
\hline 6 & 8 & Berputar lancar \\
\hline 8 & - 10 & Berputar Tersendat - sendat \\
\hline 10 & - 12 & Tidak Berputar \\
\hline
\end{tabular}

Dari hasil pengujian diatas didapatkan bahwa pada jarak $10 \mathrm{~m}$ remote contro/ sudah sulit menggerakan antena dengan baik. Hal ini membuktikan jangkauan maksimum dari sistem remote tilting ini adalah kurang lebih $10 \mathrm{~m}$. Hal ini juga menunjukan jarak maksimum untuk tinggi Base Station adalah sebesar $10 \mathrm{~m}$. Hal ini merupakan salah satu kekurangan dari penelitian yang diimplementasikan ini. Untuk mengatasi hal ini adalah dengan cara memperbesar jarak jangkau dari sistem ini yaitu dengan meningkatkan penguatan dari amplifier pada transmitter yang digunakan.

\subsection{Pengujian sistem berdasarkan tingkat kemiringan antena}

Pada tahap ini dilakukan pengujian untuk menguji pergerakan motor DC yang akan mempengaruhi tingkat kemiringan antena. Pada pengujian ini diperlukan alat pendukung berupa sebuah busur derajat untuk mengukur tingkat kemiringan antena setelah dipengaruhi perputaran motor DC. Hal ini ditunjukan pada Gambar 17.

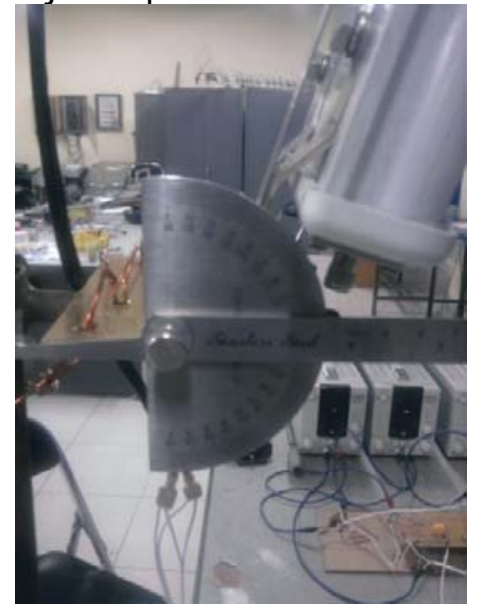

\section{Gambar 17. Pengujian remote tilting antenna berdasarkan tingkat kemiringan}

Pengujian dilakukan dengan menggeser logam pengait yang digerakan dengan menggunakan perputaran ulir berdasarkan control dari transmitter pada remote control. Pengujian hanya satu arah saja yaitu hanya arah maju saja dengan cara menggeser stick kea rah atas. Gambar 18 menunjukan grafik yang menunjukan perubahan jarak logam berkait terhadap tingkat kemiringan antena. 


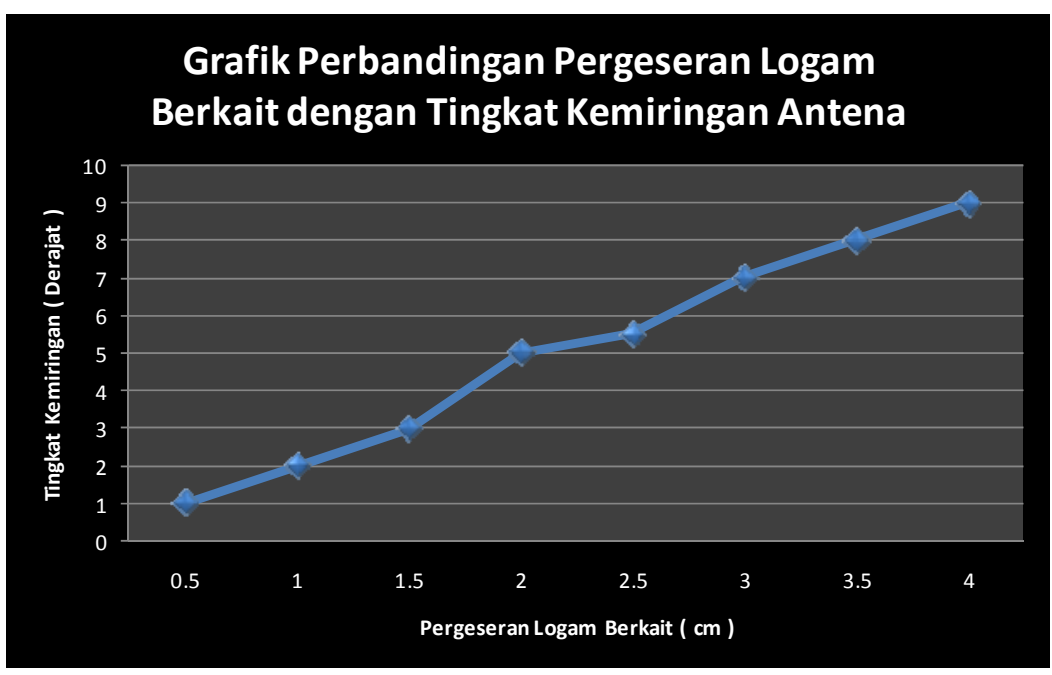

\section{Gambar 18. Grafik Perbandingan Pergeseran Logam dengan Kemiringan Antena}

Pada pengujian ini didapatkan bahwa dengan membuat logam berkait agar bergeser sebesar $0.5 \mathrm{~cm}$ akan membuat kemiringan antena sekitar 1 derajat. Ketidaktepatan nilai pengujian disebabkan oleh paralaks mata yang tidak tepat. Pada grafik tersebut juga terlihat hasil yang didapatkan menunjukan grafik yang linier. Hal ini berarti bahwa perubahan akan tetap baik dengan jarak berapapun sampai terdapat keterbatasan dari mekanik sistem.

Pada kondisi real, sebuah provider yang akan melakukan optimasi sebuah sistem telekomunikasi akan mengubah dari kemiringan antena tanpa memperdulikan besar pergeseran ataupun kemiringan dari antena. Hal ini dimaksudkan sudut kemiringan tidak terlalu menjadi tolak ukur performa sistem telekomunikasi yang dirancang. Untuk menunjukan kinerja system telekomunikasi yang telah dirancang dengan cara trying error yaitu dengan cara menggeser sedikit demi sedikit antenna dan melihat hasilnya pada software di Laptop yang digunakan sampai hasil yang diinginkan dapat tercapai dengan baik.

\section{KESI MPULAN}

\subsection{Kesimpulan}

Dari hasil perancangan, implementasi, dan pengujian sistem remote tilting antenna pada penelitian ini, maka dapat diambil kesimpulan beberpa hal yaitu sebagai berikut :

1. Penelitian ini telah dapat diimplementasikan dengan baik. Hal ini dapat dibuktikan dengan bekerjanya setiap komponen dari remote tilting antenna ini sehingga telah menghasilkan kinerja sesuai dengan yang diharapkan.

2. Pergerakan antena telah sesuai dengan yang diharapkan yaitu bergerak dengan sudut kemiringan besar dan kecil sesuai dengan contro/ yang digunakan pada transmitter.

3. Jangkauan dari remote control yang digunakan di transmitter hanyalah $10 \mathrm{~m}$ saja.

4. Tingkat kemiringan antena dibandingkan dengan pergeseran logam berkait telah menunjukan hasil yang linear. Setiap pergeseran $0,5 \mathrm{~cm}$ akan menyebabkan perubahan kemiringan antenna sebesar 1 derajat. 
Perancangan dan Implementasi Sistem Remote Tilting Antenna untuk aplikasi Base Station

\subsection{Saran}

Adapun tindak lanjut dari penelitian ini adalah sebagai berikut :

1. Jarak jangkauan transmitter diperbesar dengan cara meningkatkan penguatan atau gain dari rangkaian amplifier pada transmitter.

2. Tegangan untuk men-supply motor DC perlu diperbesar guna mempercepat rotasi dari ulir pada motor tersebut. Hal ini menyebabkan pergerakan antenna akan semakin cepat pula.

\section{DAFTAR RUJ UKAN}

B. Asep. (2008). Perancangan dan Realisasi Modem FSK untuk Komunikasi Powerline Carrier. Bandung : Institut Teknologi Nasional.

Benner, E. and Sesay, A.B.. (1996). Effects of Antenna height, antenna gain, and pattern down-tilting for Cellular mobile radio, IEEE Trans. Veh. Technol., 45, 217-224.

I. Forkel, A. Kemper, R. Pabst, R. Hermans. (2006). The Effect of Electrical and Mechanical Antenna Down-tilting In UMTS Networks. Germany : Communication Networks, Aachen University of Technology.

M.V.S.N. Prasad, M.M. Gupta, S.K. Sarkar and Iqbal Ahmad. (2005). Antenna Beam Tilting Effects In Fixed And Mobile Communication Links, Radio and Athmospheric Sciences Division, National Physical Laboratory, Dr. K.S. Krishnan Road. India : New Delhi.

S., Paul. (2000). Practical Electronics for Inventors. New York, USA: McGraw-Hill. 